\title{
CDC42 wt Allele
}

National Cancer Institute

\section{Source}

National Cancer Institute. CDC42 wt Allele. NCI Thesaurus. Code C49450.

Human CDC42 wild-type allele is located in the vicinity of 1 p36.33 and is approximately 22 $\mathrm{kb}$ in length. This allele, which encodes PITSLRE serine/threonine-protein kinase CDC2L1 protein, is involved in signal transduction pathways that control diverse cellular functions such as: cell morphology, migration, endocytosis and cell cycle progression. 